\title{
RELATION BETWEEN MINERALOGY, GEOCHEMISTRY AND DURABILITY OF SOME ALKALINE ROCKS, SOUTH EASTERN DESERT, EGYPT
}

\author{
Abd El Ghaffar, N., I.; Belal, Z. L.; and Ismail, A, I, M. \\ Geological Sciences Department, National Research Centre, Dokki, 12622 Cairo, Egypt
}

\begin{abstract}
The use of mineralogical characteristics, chemical analysis and mechanical characteristics in addressing the behavior of some alkaline rocks to resist weathering action is discussed in the present research paper. The alkaline rocks outcropping at two selected areas in the southern Eastern Desert, namely Hamrat Salma and Abu Khrug are studied.

Field relation, petrography and chemical analysis of the rocks in areas, durability and unconfined compressive strength were done. Durability and unconfined compressive strength tests evaluate the resistance of the studied alkaline rocks to natural weathering.

The studied alkaline rocks in both areas are classified mineralogically and chemically as trachyte, and syenite. In Hamrat Salma, the alkaline rocks are represented by trachyte, whereas in Abu Khrug area, they are discriminated to trachy- dacite and syenite. All the studied alkaline rocks have alkaline affinity and emplaced in anorogenic tectonic regime.

The results of compressive strength and durability of Hamrat Salma trachyte and Abu Khrug syenite showed very strong strength. The lowest value was obtained from syenite with xenoliths and trachyte of Abu Khrug showing medium strength. Negative relation between uniaxial compressive strength and durability is recorded. The existence of xenoliths, veins and porphyritic texture create a weak relationship. There is a linear relationship between compressive strength and some major oxides $\left(\mathrm{SiO}_{2}, \mathrm{Al}_{2} \mathrm{O}_{3}\right.$ and $\left.\mathrm{Na}_{2} \mathrm{O}\right)$ for the rock types. Also, a direct relation between durability and $\left(\mathrm{Fe}_{2} \mathrm{O}_{3}, \mathrm{~K}_{2} \mathrm{O}\right)$ was recorded.
\end{abstract}

Keywords: Alkaline rocks, Mineralogy, Chemical Analysis, Mechanical Properties, Durability.

\section{INTRODUCTION}

The Precambrian basement complexes of Egypt are created during the Pan African orogeny and ended with a series of post orogenic alkaline magmatism (rift related) forming ring complexes, stocks and volcanic plugs continued to the Cretaceous. Abu Khrug ring complex reported to the youngest alkaline magmatic activity of late Cretaceous age having $89 \pm 2$ Ma (Serecsists et al. 1981; Lutz et al. 1988), whereas the alkaline volcanic activity result in the extrusion of trachytic plugs is reported to the Mesozoic (191-74) Ma (Meneisy \&, Kreuzer, 1974).

The plutonic rocks nepheline syenite and their volcanic equivalent are attractive products for building and ornamental purposes (Vargas et al., 2002, Jimoh \& Raji, 2011, Graue et al., 2012, Motoki et al., 2015 and Careddu \& Grillo, 2019). These rocks are rare in nature with alkaline characters and essentially found in extensional tectonic regimes. The alkaline rocks are those of higher alkalis $(\mathrm{Na}, \mathrm{K})$ content which accommodated in feldspar, felspathoids, amphiboles and pyroxenes (Mogahed, 2016).

Building, ornamental or dimensional stones are natural rocks belong to certain varieties of igneous, metamorphic and some sedimentary rocks which are distinguished by high hardness, strength and resistance to climate changes. These rocks are distinguished by beauty, durability, attractive colors and textures Ornamental stones have been used by many civilizations in the building of homes, temples and other monuments. The use of rare and beautiful stone was especially evident in ancient Greek and Egyptian monuments and statues. Ornamental stones are used as polished slabs in different purposes as wall facing stones, floors, curb stones, paving stones, stairs, counter tops or aggregates to display 


\section{Abd El Ghaffar, et al.}

ornamentation and durability to the buildings. Some varieties of furniture, statues, tiles, mosaics and other objects of ornamentation are made of these rocks. Building stones or natural rocks are the main materials of the construction industry. Stones have been widely used in large amount of critical structure systems, particularly in historical sites. Typical examples are the walls of constructions, foundations, external coverings, parks and gardens arrangements, garden walls, pavements of roads, the restoration of historical buildings, churches, mosques and minarets or landscape architecture, water spouts. Building stone required high quality standards in order to obtain the best behavior in all situations (Seigesmund and Torok, 2011). Many studies depend on the evaluation of fundamental properties such as bulk density, prosity, uniaxial compressive strength and sonic velocity ((Benavente et al. 2004; Eren and Bahali 2005; Arman et al. 2007; Cultrone et al. 2008). The lack of sufficient studies in this direction about some Egyptian stones led the authors to focus on the assessment of two rock types located in the Eastern desert of Egypt can be exploited as building stones.

In the current study the alkaline syenite and their volcanic equivalent (trachyte \&porphyritic trachyte) are preliminary estimated for building and ornamental uses from two selected area namely Abu Khrug and Hamrat Salma which located in the Eastern Desert of Egypt.

\section{GEOLOGICAL SETTING}

\section{Trachyte of Hamrat Salma}

According to Khalil (2009) the exposed rocks of Hamrat Salma Fig 1 are geochronogically arranged as 1.Foliated metagabbros, 2. Psammitic gneisses, 3. Gneissic granitoids and leucocratic granites, 4 . White pegmatite bodies, 5. Serpentinite rocks, 6. Metapyroclastics, 7. Non-foliated Metagabbros, 8. Dokhan volcanics, 9. Igla formation, 10. Dykes and veins, 11. Trachyte plugs and sheets.

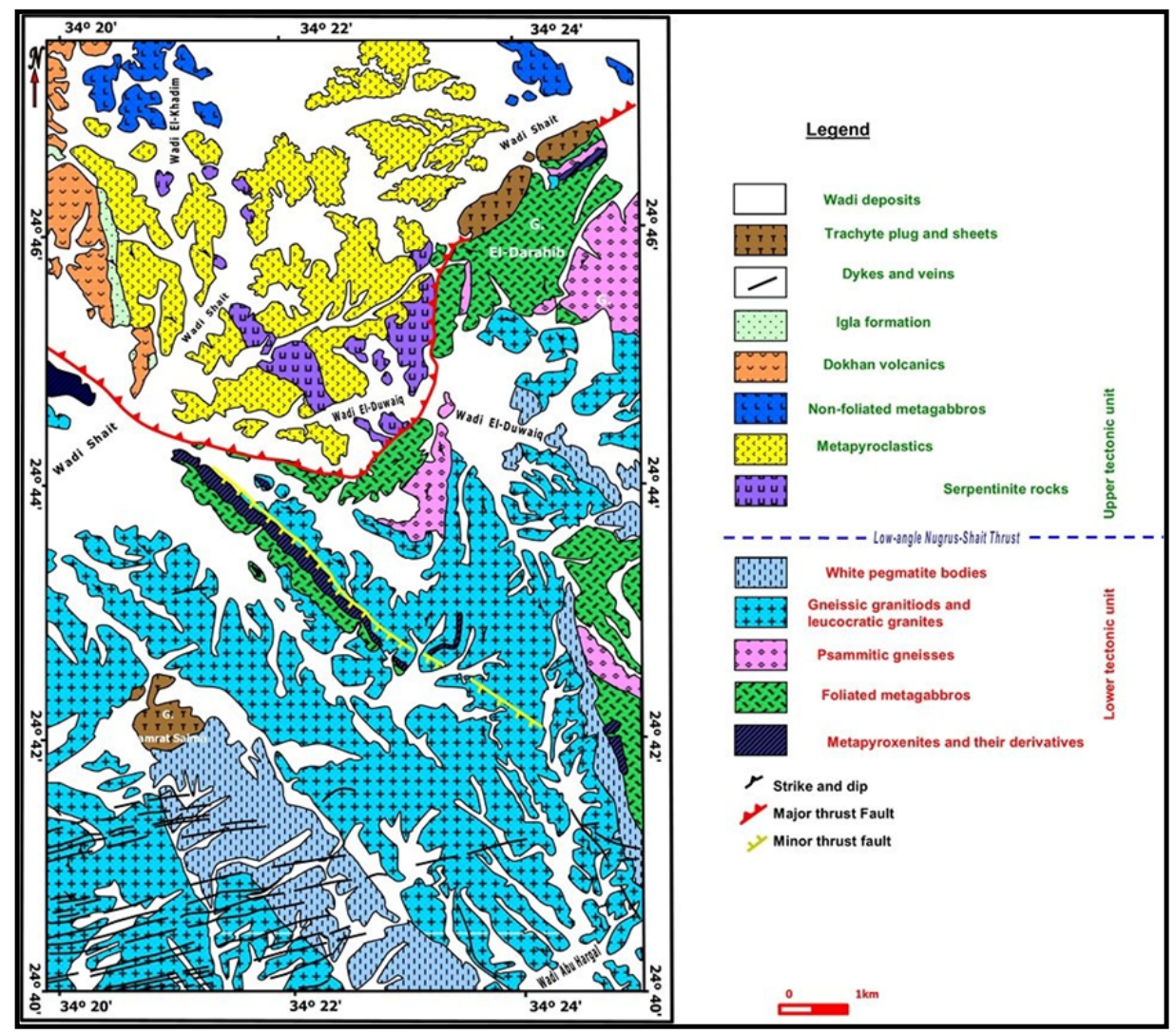

Fig. 1: Geological map of Hamrat Salam area after Khalil, 2009.

Trachytes of Hamrat Salma area are considered as the youngest rock unit in the studied area. These rocks form plugs of irregular or subcircular masses and sheets. They forms high mountains and form the highest peak in the area and mainly extrude the gneissose granite Fig. 2 (A). They are hard, massive, non- 
Relation between mineralogy, geochemistry and durability of some alkaline rocks

porphyritic dark grey and reddish in colour with trachytoidal texture, formed of feldspar laths, aegirine and iron oxide granules.

\section{Abu Khrug area}

According to El Afandy et al., 2013, the exposed rocks of Abu Khrug area (Fig. 2) are composed of extrusions of volcanic rocks comprising mainly alkaline rhyolite and alkaline trachyte rocks at the center of the pluton followed by intrusions of alkaline gabbroic and alkaline syenitic rocks comprising quartzsyenite, syenite and nepheline syenite.

Trachytes of Abu Khrug are associated with other volcanic rocks (Rhyolite and Alkaline rhyolite) displaying the highest summit of these volcanic association (Fig. 4 A and B). These rocks are confined to the western part of Gabal Abu Khrug intruded by syenitic rocks to the east.

Syenites of Abu Khrug area are exposed in the studied area as scattered masses and hills to the western part. They form an incomplete ring intrusion. These rocks are moderately weathered with gradational contact with the other rocks (Fig. $4 \mathrm{~A}$ and B).

Fig. 2: Geological map of Abu Khrug area after mogahed, 2016.
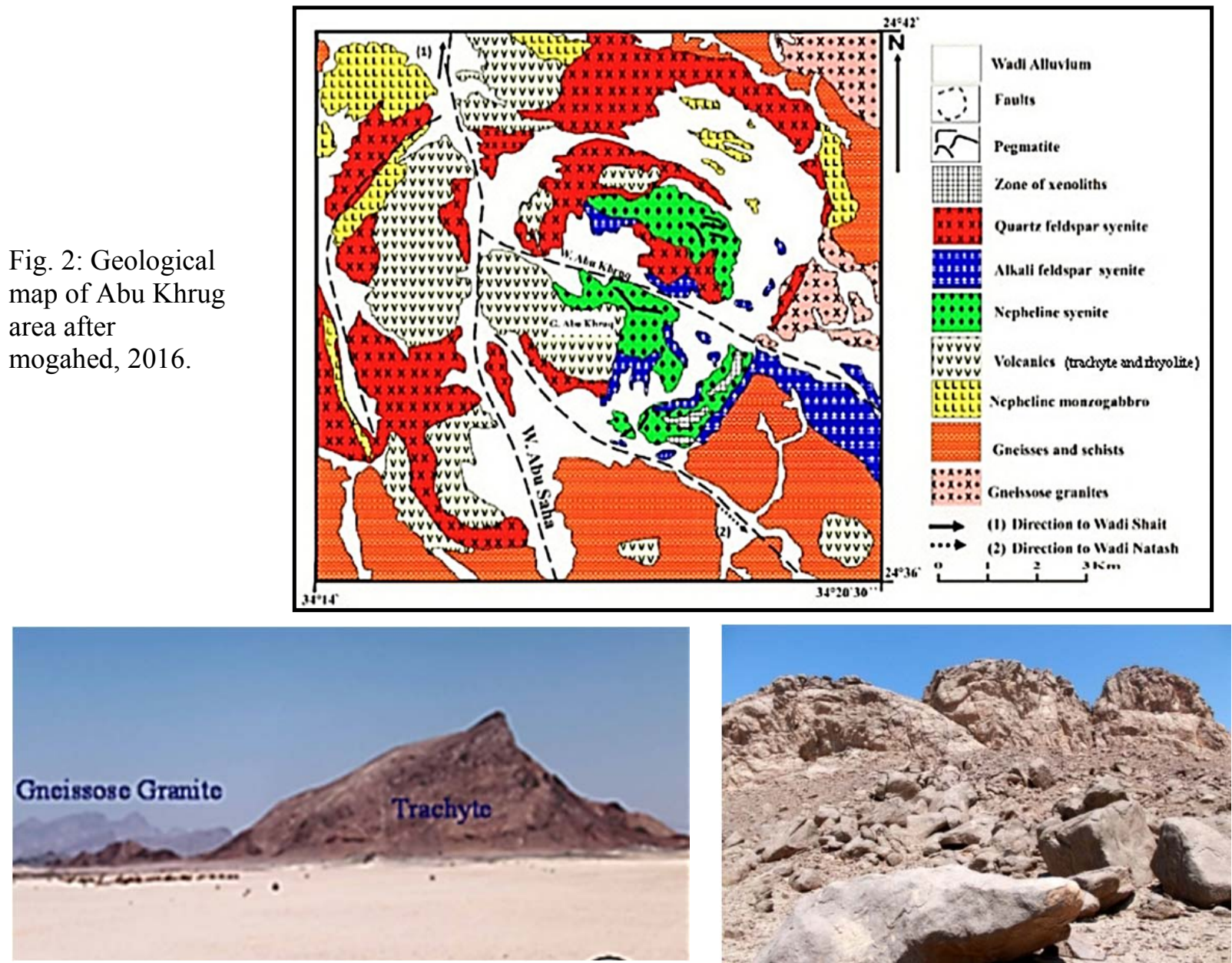

Fig. 3; A. Distant view of Homret salma trachyte mass extrudes the Precambrian gneissose granite, B. Close view of the trachyte boulders at Homret Salma plug.

\section{Petrography}

Hamrat Salma trachytes are hard, massive rocks with gray color, the rocks do not have significant variations in textures, grain sizes and types of alterations. Microscopically; the rocks are mainly composed of nepheline and alkali feldspars. The rocks typically display trachytic texture (Fig. 5A). Iron oxides and chlorite are recorded as secondary phases. 

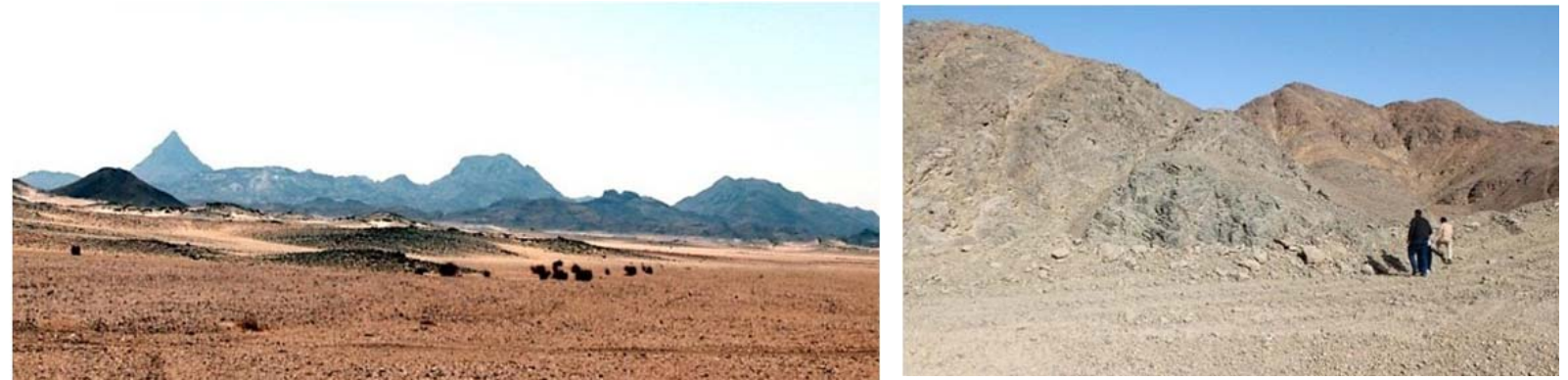

Fig. 4: A. Distant view of Abu Khruq Ring complex. B. Close view of the trachyte boulders at Homret Salma plug. B) Nepheline syenite displaying moderate weathering.

Abu Khrug trachytes are hard, massive rocks displaying porphyritic texture in hand specimen and thin sections. The rocks exhibit phenochrysts of nepheline or plagioclase in fine grained (nepheline and alkali feldspar) groundmass (Fig. 5B). In some cases the rocks exhibit trachytic texture and include carbonate veinlets (Fig. 5C).

Syenites are hard, massive, medium to coarse grained displaying light gray color. These rocks are mainly composed of alkali feldspar represented by perthite, nepheline, aegerine augite (Fig. 5D) with subordinate quartz and plagioclase.

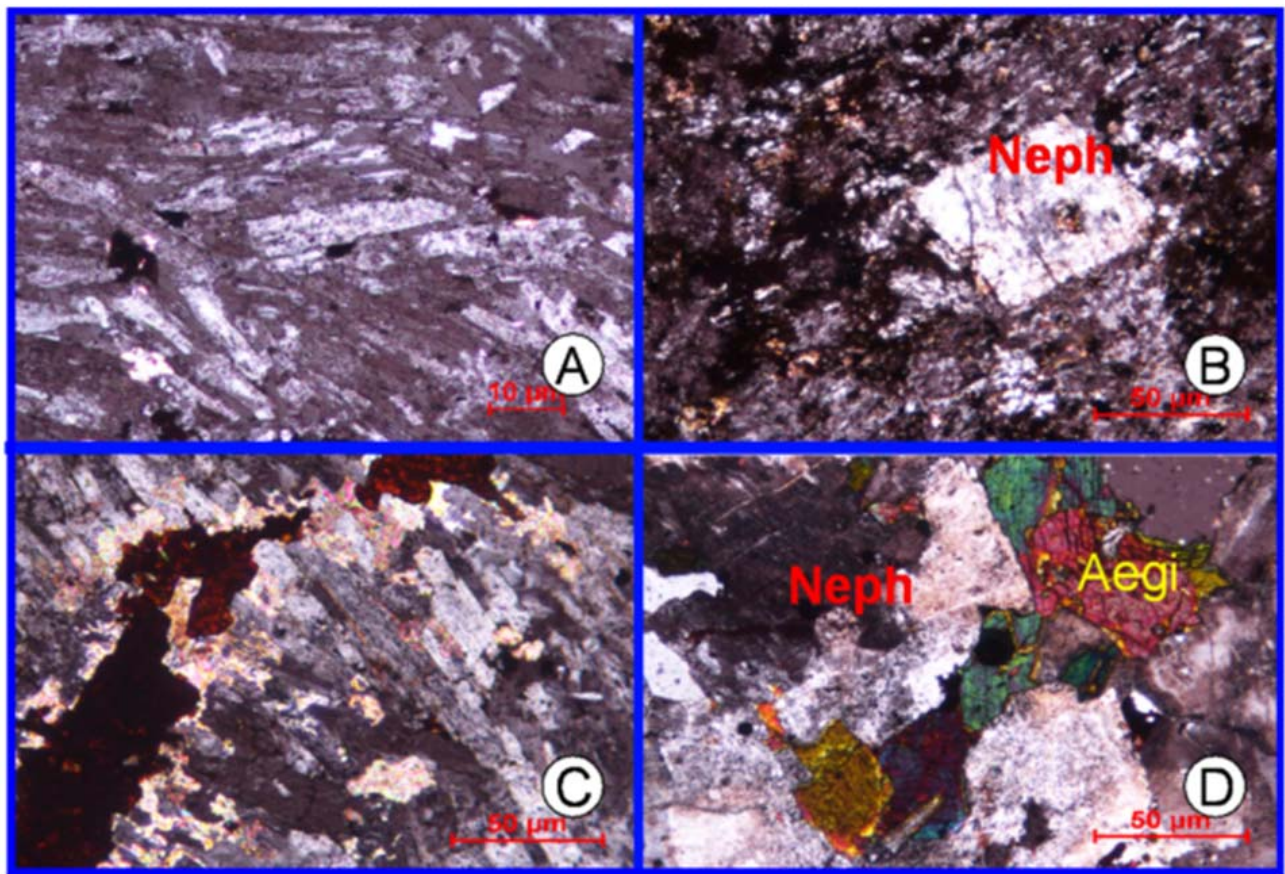

Fig. 5: A) Microphotograph of typical trachytic texture of nepheline and feldspar crystals. B) Nepheline phenocrysts embedded in a microcrystalline felsic groundmass. C) Microphotograph of carbonate veinlet in trachyte. D) Photomicrograph of syenite showing association of Aegirine (Aegi) and nepheline (Neph).

\section{Chemical Composition of the investigated rocks}

The chemical composition of the studied samples is displayed in Table 1 together with their normative compositions. According the geochemical classification diagrams of Middlemost, 1985 \&1994, the studied samples are chemically classified as trachyte, trachy-dacite and syenite (Fig. 6). Generally, the all the studied rocks follow the alkali trend according to Frost (2001) discrimination diagrams, with Ferroan characters (Fig. 7). Syenite and trachyte samples are plotted in peralkaline field whereas trachy-dacite samples have metaluminous affinity. According to Batchelor and Bowden (1985) tectonic discrimination diagram, all the studied rocks are emplaced in anorogenic tectonic regime (Fig. 8). 
Relation between mineralogy, geochemistry and durability of some alkaline rocks

Table 1: Chemical composition of the investigated rocks.

\begin{tabular}{|l|c|c|c|c|c|c|}
\hline Oxide \% & $1 \mathrm{~A}$ & $1 \mathrm{~B}$ & $2 \mathrm{~A}$ & $2 \mathrm{~B}$ & $3 \mathrm{~A}$ & $3 \mathrm{~B}$ \\
\hline $\mathrm{SiO}_{2}$ & 64.15 & 64.84 & 63.88 & 63.54 & 60.73 & 61.19 \\
\hline $\mathrm{TiO}_{2}$ & 0.13 & 0.12 & 0.44 & 0.42 & 0.53 & 0.54 \\
\hline $\mathrm{Al}_{2} \mathrm{O}_{3}$ & 15.76 & 16.27 & 14.50 & 14.53 & 12.41 & 12.62 \\
\hline $\mathrm{Fe}_{2} \mathrm{O}_{3}$ & 4.20 & 4.24 & 7.60 & 7.65 & 10.98 & 10.26 \\
\hline $\mathrm{MnO}$ & 0.09 & 0.12 & 0.13 & 0.14 & 0.25 & 0.33 \\
\hline $\mathrm{MgO}$ & 0.18 & 0.16 & 0.10 & 0.12 & 0.22 & 0.18 \\
\hline $\mathrm{CaO}$ & 1.07 & 1.28 & 0.73 & 0.77 & 0.87 & 0.99 \\
\hline $\mathrm{Na}_{2} \mathrm{O}$ & 7.64 & 7.63 & 7.54 & 7.50 & 3.60 & 2.87 \\
\hline $\mathrm{K}_{2} \mathrm{O}$ & 3.99 & 4.00 & 3.77 & 3.92 & 5.28 & 6.06 \\
\hline $\mathrm{P}_{2} \mathrm{O}_{5}$ & 0.02 & 0.02 & 0.07 & 0.07 & 0.06 & 0.06 \\
\hline $\mathrm{SO} \mathrm{F}_{3}$ & 0.08 & 0.05 & 0.03 & 0.04 & 1.73 & 1.43 \\
\hline $\mathrm{Cl}$ & 0.09 & 0.06 & 0.05 & 0.06 & 0.14 & 0.14 \\
\hline $\mathrm{L} . \mathrm{O} . \mathrm{I}$ & 1.49 & 0.09 & 0.71 & 0.80 & 2.73 & 2.85 \\
\hline \multicolumn{5}{|l|}{$\mathrm{CIPW}$} & \multicolumn{2}{|c|}{} \\
\hline $\mathrm{Q}$ & 4.38 & 4.29 & 7.10 & 6.43 & 17.95 & 19.27 \\
\hline $\mathrm{Or}$ & 23.58 & 23.64 & 22.28 & 23.17 & 31.20 & 35.81 \\
\hline $\mathrm{Ab}$ & 58.85 & 61.42 & 53.59 & 52.91 & 30.46 & 24.29 \\
\hline $\mathrm{An}$ & 0.00 & 0.00 & 0.00 & 0.00 & 2.11 & 3.65 \\
\hline $\mathrm{Ac}$ & 5.11 & 2.77 & 8.99 & 9.30 & 0.00 & 0.00 \\
\hline $\mathrm{Di}$ & 0.97 & 0.86 & 0.54 & 0.64 & 0.74 & 0.22 \\
\hline $\mathrm{Wo}$ & 1.60 & 2.14 & 0.61 & 0.68 & 0.00 & 0.00 \\
\hline $\mathrm{Hy}$ & 0.00 & 0.00 & 0.00 & 0.00 & 0.20 & 0.35 \\
\hline $\mathrm{Mt}$ & 0.00 & 0.04 & 0.00 & 0.00 & 0.00 & 0.00 \\
\hline $\mathrm{Il}$ & 0.19 & 0.23 & 0.28 & 0.30 & 0.53 & 0.71 \\
\hline $\mathrm{Hm}$ & 2.43 & 3.25 & 4.49 & 4.44 & 10.98 & 10.26 \\
\hline $\mathrm{Tn}$ & 0.07 & 0.00 & 0.72 & 0.64 & 0.61 & 0.41 \\
\hline $\mathrm{Ap}$ & 0.05 & 0.05 & 0.17 & 0.17 & 0.14 & 0.14 \\
\hline
\end{tabular}

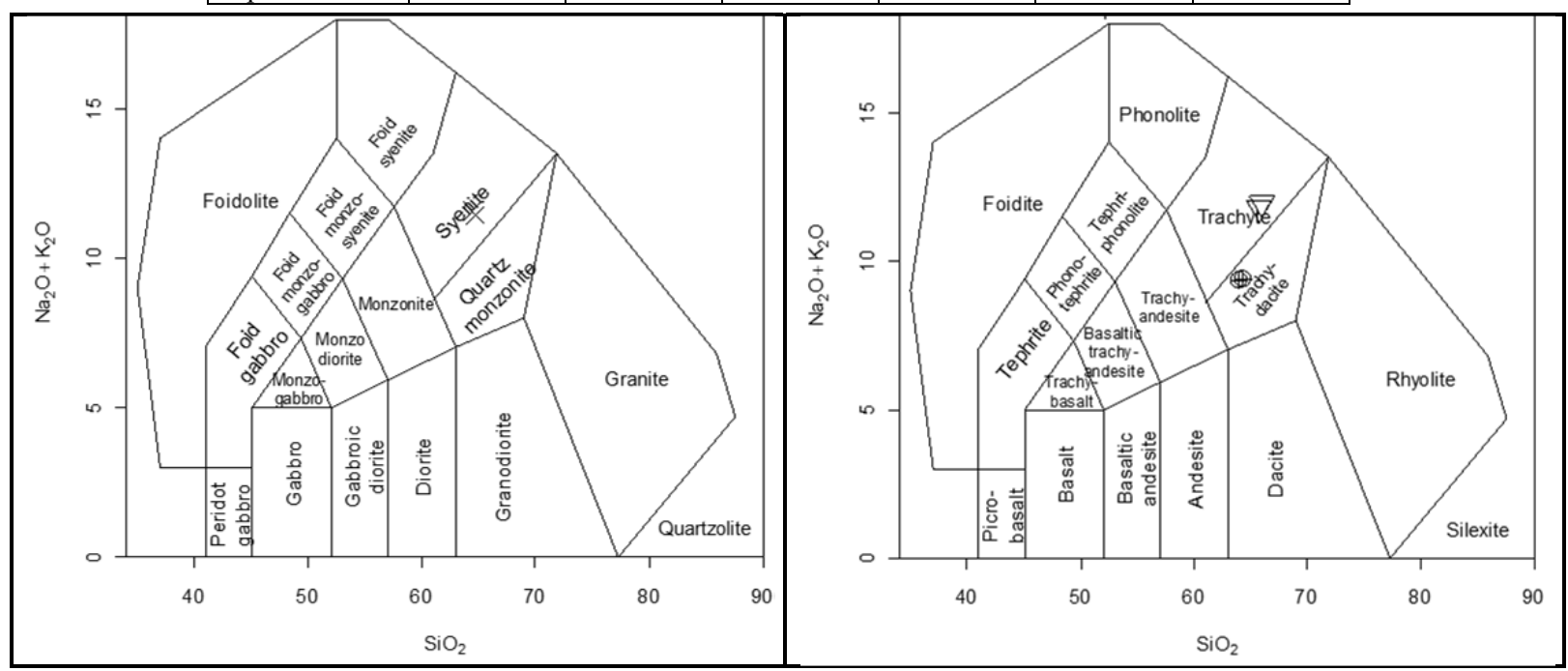

Fig. 6: Geochemical classification diagrams of Middlemost for plutonic and volcanic rocks.

\section{MATERIALS AND EXPERIMENTAL METHODS}

\section{Durability}

Durability test assesses the resistance of the studied samples to natural weathering stresses of repeated wetting and drying cycles. The test was performed in accordance with ASTM D559 (ASTM 2015) method. Syenite and trachyte samples were subjected to 12 cycles. Each sample was immersed in distilled water for 5 hours and 42 hours in an oven at $71^{\circ} \mathrm{C}$. The samples were brushed with force $13.3 \mathrm{~N}$. The changing in weight loss was determined after each cycle. After 12 cycles the total weight loos calculated as follow: 
Abd El Ghaffar, et al.

Mass loss $\%=\mathrm{A} / \mathrm{B} * 100$

A: original calculated oven dry weight minus final corrected oven dry weight. And

B: original calculated oven dry weight

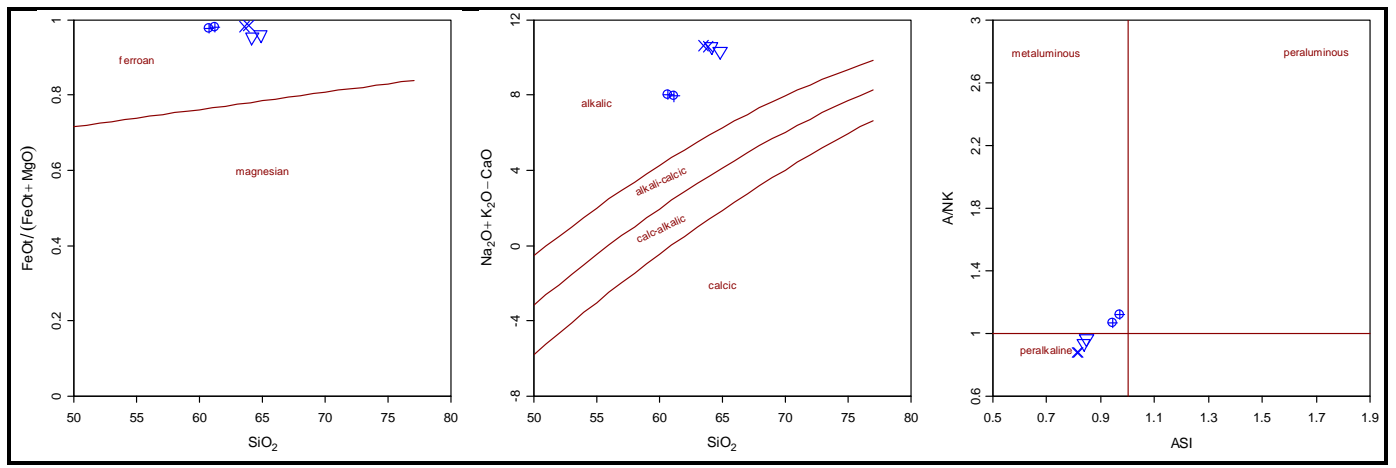

Fig. 7: Frost discrimination diagrams of the examined samples.

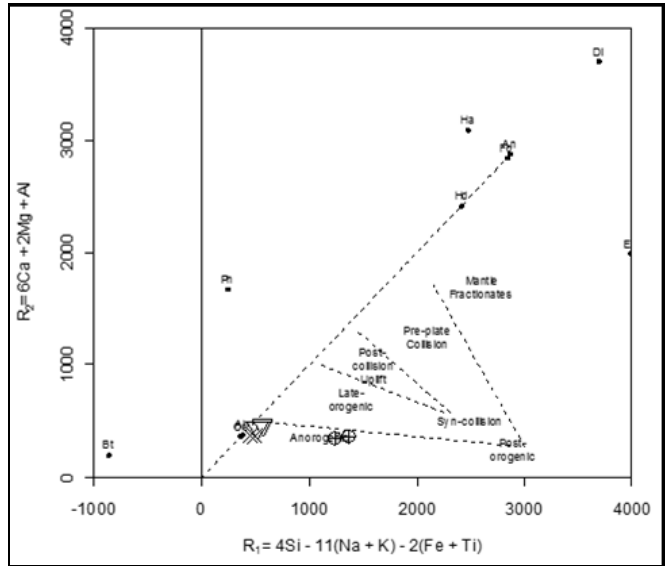

Fig. 8: Plot of the studied rocks on of tectonic setting diagram after Bachelor and Bowden (1985)

\section{Unconfined compressive strength}

Unconfined compressive strength is one of the most significant quality and design parameters of building material. This parameter direct determination in the laboratory is carried out according to American Society for Testing and Materials (ASTM, 1984). In this experimental study, the studied rock types were compressed between platens of compression testing machine by gradually applied load Fig. 9 .

Fig. 9: Schematic test setup for compressive strength.

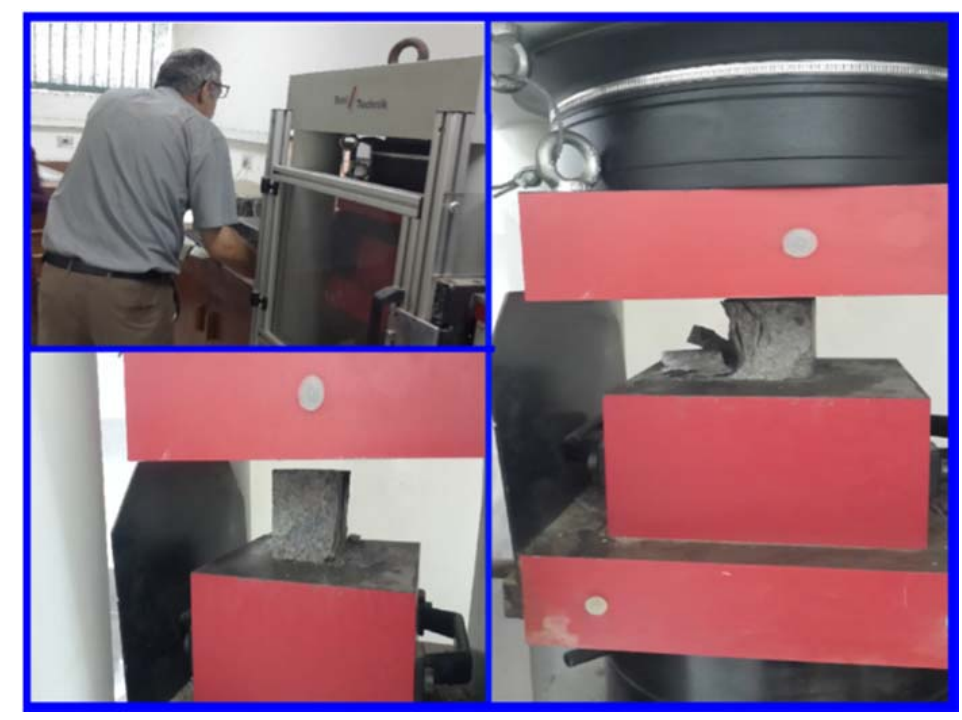


Relation between mineralogy, geochemistry and durability of some alkaline rocks

\section{Mechanical properties}

The result of compressive strength test are displayed in Table (2), In this table, the compressive strength varied from 41.5 to $145 \mathrm{~N} / \mathrm{mm}^{2}$. The highest value was measured in the rock samples (1A and $2 \mathrm{~A}$ ) very strong strength (trachyte and synite), while the lowest value was obtained from (1B) (trachyte with veins) medium strength. Depending on the comparison between the result of compressive strength in Table 1 and the classification of Franklin \& Dusscault Table 3 (1989), the rocks could be classified as medium strong and very strong strength.

Table 2: Durability and uniaxial compressive strength

\begin{tabular}{|c|c|c|c|c|c|}
\hline $\begin{array}{l}\text { Sample } \\
\text { No. }\end{array}$ & $\begin{array}{l}\text { Rock } \\
\text { type }\end{array}$ & $\begin{array}{l}\text { Uniaxial Compressive } \\
\text { strength (UCS) N/mm }\end{array}$ & $\begin{array}{l}\text { weight loss } \% \text { at } 12 \\
\text { cycles wetting and } \\
\text { drying }\end{array}$ & $\begin{array}{l}\text { Grain size } \\
\text { and texture }\end{array}$ & $\begin{array}{c}\text { Classification of UCS } \\
\text { According to } \\
\text { Franklin \& Dusscault, } 1989\end{array}$ \\
\hline $1 \mathrm{~A}$ & \multirow{2}{*}{ 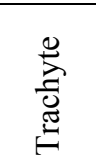 } & 138.4 & 0.56 & Fine & Very strong \\
\hline 1B & & 41.5 & 1.12 & $\begin{array}{l}\text { Fine with } \\
\text { veins }\end{array}$ & Medium strong \\
\hline $2 \mathrm{~A}$ & \multirow{2}{*}{. } & 145 & 0.28 & Coarse & Very strong \\
\hline $2 \mathrm{~B}$ & & 41.9 & 1.58 & $\begin{array}{l}\text { Coarse with } \\
\text { xenoliths }\end{array}$ & Medium strong \\
\hline $3 \mathrm{~A}$ & \multirow{2}{*}{ 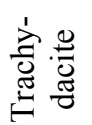 } & 51.3 & 3.63 & $\begin{array}{c}\text { Fine with } \\
\text { porphyritic }\end{array}$ & Medium strong \\
\hline $3 \mathrm{~B}$ & & 51.9 & 2.99 & Fine & Medium strong \\
\hline
\end{tabular}

The uniaxial compressive strength and durability tests consider the most important and critical parameter of rock and these tests are played a significant role in geotechnical and rock engineering projects. Figure (10) shows the interrelationship of compressive strength and the durability of the rocks under investigation. In fact, rocks of the same rock composition display significant different durability Except for 3A\&3Asamples have strong correlation with durability $\left(\mathrm{R}^{2}=0.88\right)$. As the weight loss of rock samples after 12 cycles increase, the durability decreases. There is a negative relation between weight loss $\%$ and compressive strength for homogenous rock samples (1A, 2A and 2B) Table 1 and Fig. 11). The existence of xenoliths, veins and porphyritic texture, the relation seem to be week (Tabl 3, Fig. 10). Hamrat salma trachyte is more durable than Abu Khrug trachytes (Table 1), whereas both trachytes in the two areas are more durable than syenite (Fig. 12 and Table 2).

The rock samples in both areas under investigation are classified according to Franklin \& Dusscault (1989) as medium strong and very strong (Table 3). The trachyte of Hamrat Salma and syenite of Abu Khrug are classified as very strong whereas trachyte of Abu Khrug are medium strong rocks (Tables 2 and 3 ). The existence of xenoliths and veins decrease the compressive strength of trachyte samples also the existence of porphyritic texture of syenite in Abu Khrug area decrease the compressive strength (Table 2). Hence, the mechanical properties of the studied rocks are function of their textures.

Table 3: Classification of rocks according to Franklin \& Dusseault (1989).

\begin{tabular}{|c|l|}
\hline Uniaxial compressive strength $\mathrm{N} / \mathrm{mm}^{2}$ & Classification \\
\hline$\sigma \leq 2$ & Extremely weak \\
\hline $2 \leq \sigma \leq 6$ & Very weak \\
\hline $6 \leq \sigma \leq 20$ & Weak \\
\hline $20 \leq \sigma \leq 60$ & Medium strong \\
\hline $60 \leq \sigma \leq 200$ & Very strong \\
\hline$\sigma>200$ & Extremely strong \\
\hline
\end{tabular}

\section{Regression analysis between mechanical, chemical properties and grain size}

Mechanical, chemical properties and grain size of the rock types has been a great attention in critical infrastructure system. From the previous studies, the grain size has a great influence on mechanical properties (Brace, 1961; Hugman, Friedman, 1979; Tuğrul, Zarif, 1999; Yusof and Zabidi, 2016). 
Abd El Ghaffar, et al.

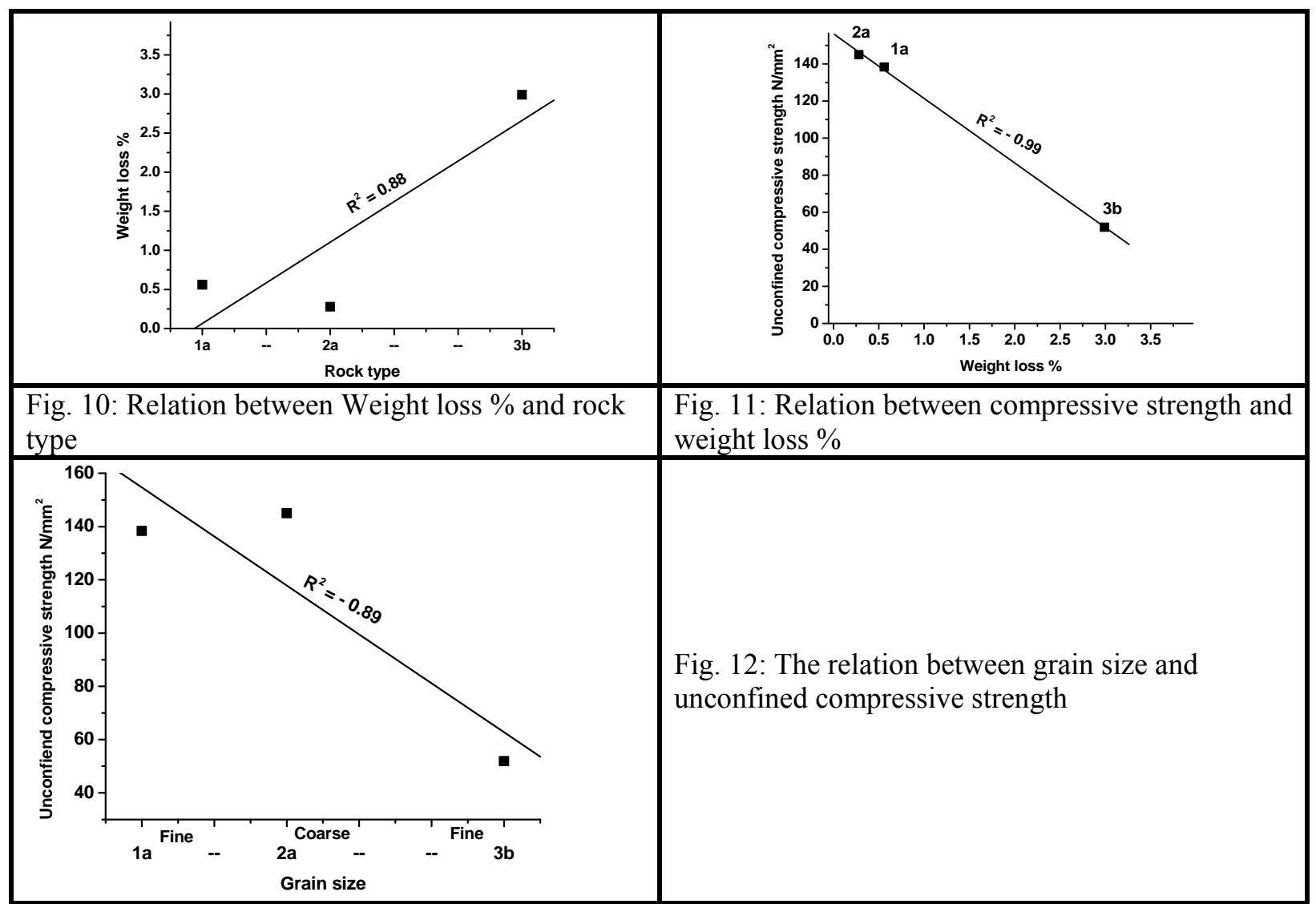

In order to characterize the relation between compressive strength and durability with chemical analysis, correlation coefficient ( $\mathrm{r}$ ) were determined for the selected rocks without xenoliths, veins or porphyritic texture. As can be seen from Figs. 13 and 14 in each case, the best fitted relation was found to be appearing as linear curves.

The plotting of the compressive strength values against and chemical composition of the studied samples is displayed in Fig 13. There is a linear relationship between compressive strength and $\left(\mathrm{SiO}_{2}\right.$, $\mathrm{Al}_{2} \mathrm{O}_{3}$ and $\mathrm{Na}_{2} \mathrm{O}$ ) for samples (1A, 2A and 3B). A strong correlation ( $\mathrm{R}=0.99,0.89$ and 99$)$ was also found between compressive strength and $\left(\mathrm{SiO}_{2}, \mathrm{Al}_{2} \mathrm{O}_{3}\right.$ and $\left.\mathrm{Na}_{2} \mathrm{O}\right)$. Similarly a liner relationship was observed between durability and $\left(\mathrm{Fe}_{2} \mathrm{O}_{3}\right.$ and $\left.\mathrm{K}_{2} \mathrm{O}\right)$ with a correlation coefficient of 0.77 and 0.99 respectively Fig. 14(B).

\section{SUMMARY AND CONCLUSIONS}

The relation between petrological characters and mechanical properties of syenite and trachyte was studied in detail in this paper. The studied syenite and its volcanic equivalent (trachyte) outcropping at Eastern Desert of Egypt in the two areas of study, Abu Khrug and Hamrat Salma areas. According to the chemical analysis and mineralogical characteristics, the rocks in Hamrat Salma are represented by trachyte where the rocks exposed in Abu Khrug are represented by trachyte-dacite and syenite. Durability and unconfined compressive strength tests evaluate the resistance of the studied samples to natural weathering.

The rocks exposed at Hamrat Salma area are represented by foliated metagabbros, psammitic gneisses, gneissic granitoids and leucocratic granites, white pegmatite bodies, serpentinite rocks, metapyroclastics, non-foliated metagabbros, dokhan volcanics, Igla formation, dykes and veins and trachyte plugs and sheets. Trachyte under study is considered as the youngest rock unit in the studied area and forms plugs of irregular or sub-circular masses and sheets. It extrudes the gneissose granite. Petrologically, trachyte rocks form high mountains and form the highest peak in the area. They are hard, massive, non-porphyritic dark 


\section{Relation between mineralogy, geochemistry and durability of some alkaline rocks}

grey and reddish in colour with trachytic texture. They are formed of feldspar laths, aegirine and associated with iron oxide and chlorite as accessory and secondary minerals respectively.

The alkaline rocks of Abu Khrug area are represented by alkaline rhyolite and alkaline trachyte rocks at the center of the pluton followed by intrusions of alkaline gabbroic and alkaline syenitic rocks comprising quartz- syenite, syenite and nepheline syenite. Trachyte rocks of Abu Khrug area are associated with rhyolite and alkaline rhyolite. These rocks are confined to the western part of Gabal Abu khrug intruded by syenitic rocks to the east. Syenites of Abu Khrug area are exposed in the studied area as scattered masses and hills to the western part. Mineralogially, Abu khrug trachytes are hard, massive rocks displaying porphyritic texture. The rocks exhibit phenochrysts of nepheline or plagioclase in fine grained groundmass of nepheline and alkali feldspar. Some carbonate veinlets are recorded in Abu Khrug trachyte.

On the other hand, Abu Khrug syenites are hard, massive; medium to coarse grained and composed mainly of perthite, nepheline and aegerine augite with subordinate quartz and plagioclase.

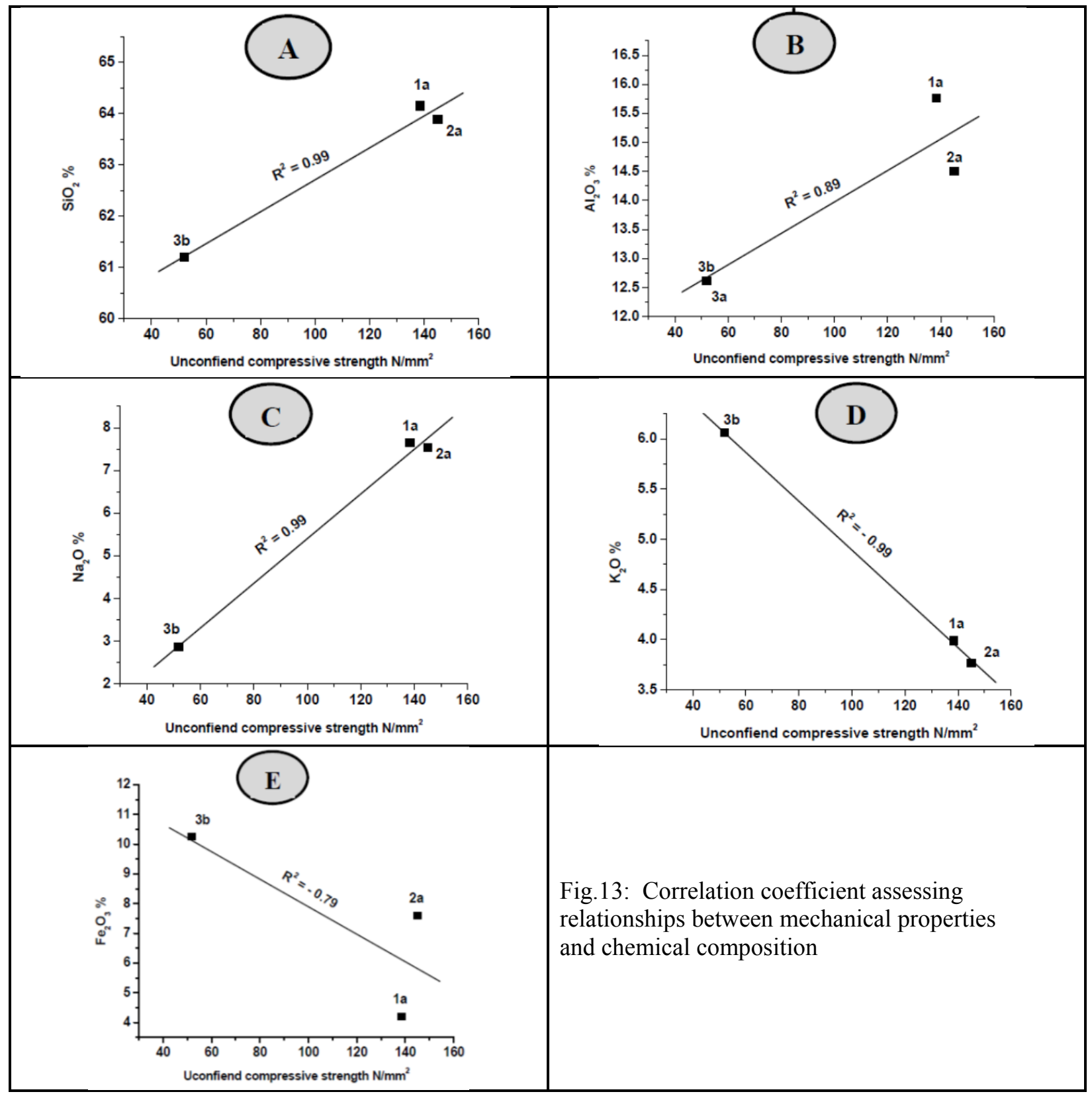


Abd El Ghaffar, et al.

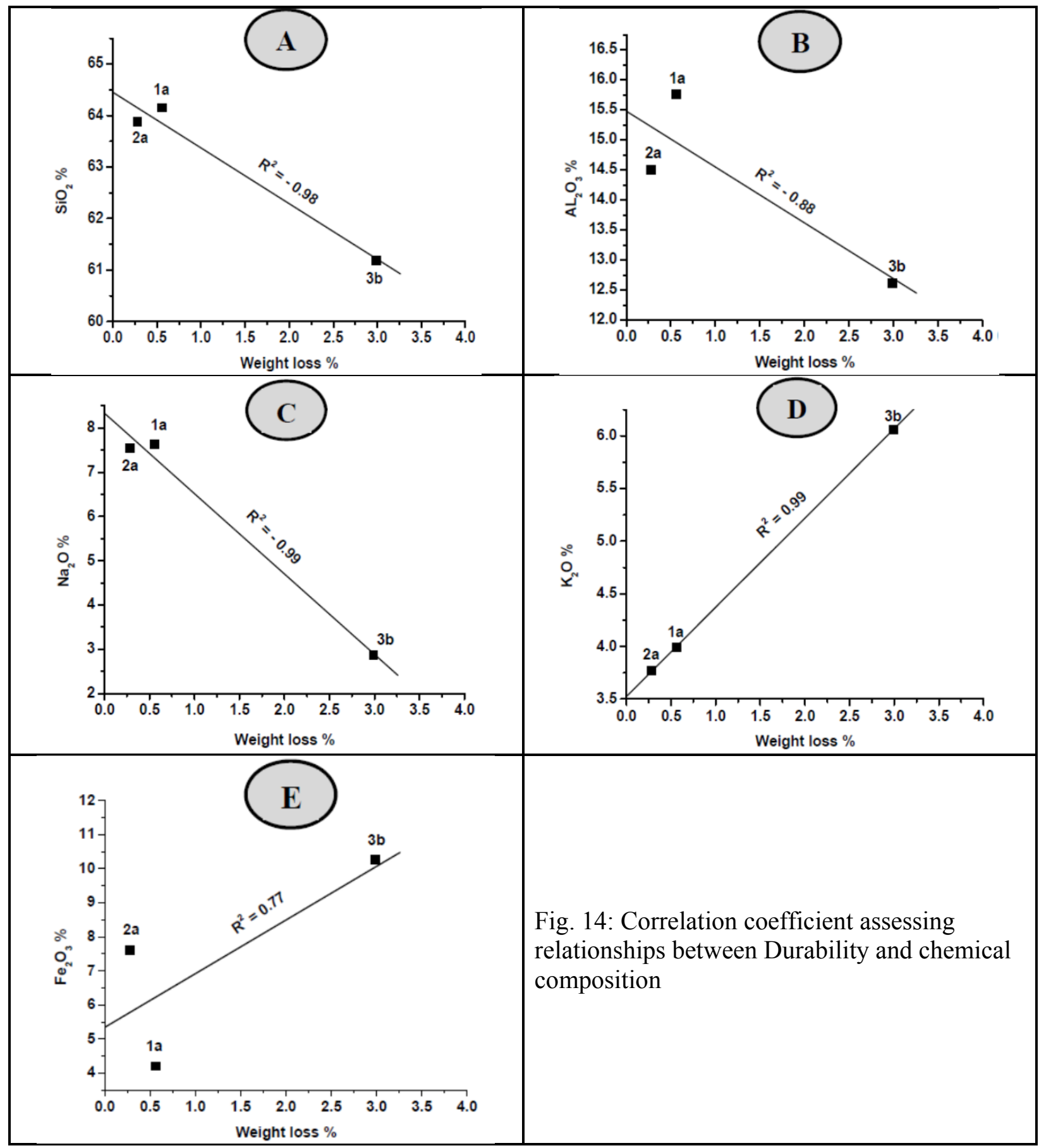

The result of compressive strength values of the studied rocks in both areas varied from 41.5 to 145 $\mathrm{N} / \mathrm{mm}^{2}$.The highest values were measured in the rock samples of Hamrat Salma trachyte and Abu Khrug syenite showing very strong strength. The lowest value was obtained from syenite with xenoliths and trachyte of Abu Khrug showing medium strength. The highest strength value $\left(145 \mathrm{~N} / \mathrm{mm}^{2}\right)$ in Hamrat Salma occurs in trachyte rocks of fine grain texture, with increasing the veins especially carbonate composition, the strength decreased $\left(41.5 \mathrm{~N} / \mathrm{mm}^{2}\right)$. Trachyte in Abu Khrug area exhibited porphyritic texture and the compressive strength decreased ranging from $51.3 \mathrm{~N} / \mathrm{mm}^{2}$ to $51.9 \mathrm{~N} / \mathrm{mm}^{2}$. Coarse grain texture syenite of Abu Khrug has high strength parameter $\left(145 \mathrm{~N} / \mathrm{mm}^{2}\right)$ and with increasing the xenoliths in syenite rocks, the compressive strength decreases $\left(41.9 \mathrm{~N} / \mathrm{mm}^{2}\right)$. 


\section{Relation between mineralogy, geochemistry and durability of some alkaline rocks}

Durability is simply assigned as its ability to resist weathering action. It increases with increasing the compressive strength and decreasing the weight loss\%. The maximum weight loss (3.63\%) was recorded for porphyritic syenite of Abu Khrug. Furthermore, fine grain trachyte of Hamrat Salma and coarse grain syenite of Abu Khrug displayed satisfactory resistance weathering (weight loss values were $0.56 \%$ and 0.285 respectively). Hamrat Salma trachyte containing veins has weight loss $1.12 \%$ confirming that it is less durable than Hamrat Salma trachyte without veins. On the other hand, the trachyte of Abu Khrug has weight loss ranging from 2.99 to $3.63 \%$ confirming that it is less ability to weathering than the other rock. Syenite of Abu Khrug has high ability to resist weathering, where it has low weight loss values $(0.28 \%)$ and with increasing the xenolith in syenite, the weight loss increases (1.58\%).

Direct relation between uniaxial compressive strength and durability was observed. As the weight loss of rock samples after 12 cycles increase, the durability decreases. There are found negative relation between weight loss $\%$ and compressive strength for homogenous rock samples. The presence of xenoliths, veins and porphyritic texture make the relation week. There is a linear relationship between compressive strength and some major oxides $\left(\mathrm{SiO}_{2}, \mathrm{Al}_{2} \mathrm{O}_{3}\right.$ and $\left.\mathrm{Na}_{2} \mathrm{O}\right)$ for the rock types. There is also strong correlation between compressive strength and $\mathrm{SiO}_{2}, \mathrm{Al}_{2} \mathrm{O}_{3}, \mathrm{Na}_{2} \mathrm{O}$. Similarly a liner relationship was observed between durability and $\mathrm{Fe}_{2} \mathrm{O}_{3}, \mathrm{~K}_{2} \mathrm{O}$.

\section{REFERENCES}

Arman H, Ramazanoglu S, Akinci A (2007): Mechanical and physicalproperties of the Kandira stone, Kandira, Turkey. Bull Eng Geol Environ 66:331-333.

ASTM (1984): American Society for testing and materials, Standard test method for unconfined compressive strength ofintact rock core specimens, Soil and rock, building stones: annual book of ASTM standards, 4.08, Philadelphia, Pennsylvania Barton.

ASTM (2015): Standard test methods for wetting and drying compacted soil-cement mixture. West Conshohocken, philadephia.

Batchelor, R. A. and Bowden, P. (1985): Petrogenic interpretation of granitoid rock series using multicationic parameters. Chem. Geol. 48, 43-55.

Benavente D, Garci'a del Cura MA, Fort R, Ordo'ñez S (2004): Durability estimation of porous building stones from porestructure and strength. Eng Geol 74:113-127

Brace W F. (1961): "Dependence of fracture strength of rocks on grain size. Bul. Mineral Industries Experiment Station, Mining Engineering Series. Rock Mechanics, 76: 99-103.

Careddu, N, and Grillo, S. (2019): Trachytes" from Sardinia: Geoheritage and Current Use Sustainability, 11, 3706; http://dx.doi.org/10.3390/su11133706.

Cultrone G, Russo LG, Calabro` C, Uros`evic `` M, Pezzino A (2008): Influence of pore system characteristics on limestone vulnerability:a laboratory study. Environ Geol 54:1271-1281.

El Afandy, A. H., El Nahas, H. A., Dawood, N.A., Asran, H. M., (2013): Geochemistry, mineralogy, and radioactivity of upper Cretaceous Abu Khruq ring complex, south Eastern desert, Egypt. Arabian J. Geosci. 6, 2855-2871.

Eren O, Bahali M (2005): Some engineering properties of natural building cut stones of Cyprus. Constr Build Mater 19:213-222.

Franklin, J.A.,and Dusseault, M. B.,(1989): Rock Engineering, McGraw Hill,USA.

Frost B.R. et al. (2001): A Geochemical Classification for Granitic Rocks. J. Petrol. 42, 2033-2048.

Hugman R. H. H., Friedman M. (1979): Effect of texture and composition on mechanical behaviour of experimentally deformed carbonate rocks. Amer. Assoc. Petrol. Geologists Bull. 63 (9): 1478-1489

Jimoh, M. T. and Raji, I. O. (2011): Economic Prospects of Nepheline Syenites Occurring Around Awo, Southwestern, Nigeria Journal of Emerging Trends in Eng. App. Sci. (JETEAS) 2 (4): 606-609.

Khalil, A. A. (2009): Geology, petrography, geochemistry and petrogenesis of the Pan-African basement rocks in the area around Gabal Hamrat Salma-Wadi shait terrain, south Eastern Desert, Egypt. M. Sc. Benha Univ. Egypt 145p.

Lutz T. M., Foland K. A., Faul H, and Srogi L. A. (1988): The strontium and oxygene isotopic record of hydrothermal alteration of syenites from Abu Khruq complex, Egypt. Contrib Mineral. Petrol. 98, 212-223. 
Abd El Ghaffar, et al.

Meneisy, M. Y., Kreuzer, H. (1974): Potassium-argon ages of nepheline syenite ring complexes in Egypt. Geol Jb D-9: 33-39.

Middlemost, E. A. K. (1985): Magmas and magmatic rocks. Longman Group Ltd., Essex.

Middlemost, E. A. K., (1994): Naming material in the magma/igneous rock system. Earth-Sci. Rev., 37, 215-224.

Mogahed M. M. (2016): Petrogenesis of cogenetic silica oversaturated and -undersaturated syenites of Abu Khruq ring complex, south Eastern Desert, Egypt. J. Afr. Earth Sci 124: 44-62.

Motoki, A., Vargas, T., Motoki, K., and Sichel, S., (2015): Geology and petrography of nepheline syenite for ornamental use at Marapicu peak, Mendanha intrusive complex, state of Rio De Janeiro, Brazil. São Paulo, UNESP, Geociências, 34, 3, 348-363.

Serecsists CMc, Faul H, Foland KA, Hussein AA, Lutz TM (1981): Alkaline ring complex in Egypt: their ages and relationship in time. J. Geophy. Res 86: 3009-3013.

Siegesmund S., and Dürrast H. (2011): Physical and mechanical properties of rocks. In: Siegesmund S, Snethlage R. (eds) Stone in architecture - properties, durability, $4^{\text {th }}$ ed. Springer, Berlin, 97-226.

Siegesmund, S. Middendorf, and Oyhantcaba, P. (2012): Requirements for replacement stones at the cologne cathedral - a systematic approach to general criteria of compatibility 12th International Congress on the Deterioration and Conservation of Stone Columbia University, New York.

Tuğrul, A., and Zarif I. H. (1999): Correlation of mineralogical and textural characteristics with engineering properties of selected granitic rocks from Turkey. Eng. Geol., 51(4): 303-317.

Vargas, T.; Motoki, A. and Neves, J. L. P. (2002): Rochas ornamentais do Brasil, seu modo de ocorrência geológica, variedade tipológica, explotação comercial e utilidades como materiais nobres de construção. Revista de Geociências, UFF, Niterói, 2, 2, 119-132.

Yusof N Q A M., and Zabidi H. (2016): Correlation of mineralogical and textural characteristics with engineering properties of granitic rock from Hulu Langat, Selangor. Proc. Chem., 19: 975-980 
Relation between mineralogy, geochemistry and durability of some alkaline rocks

$$
\begin{aligned}
& \text { العلاقة بين التركيب المعدني و جيوكيميائية ومتانة بعض الصخور القلوية بالصحراء الثرقية-مصر } \\
& \text { نهلة ابراهيم عبد الغفار و زينب لطفي بلال و علي اسماعيل محمد اسماعيل } \\
& \text { قسم العلوم الجيولوجية - المركز القومي للبحوث } \\
& \text { الخلاصة }
\end{aligned}
$$

تم مناقثة استخدام الخصائص المعدنية والتحليل الكيميائي والخواص الميكانيكية لتحدي قدرة بعض الصخور القلوية على مقاومة عمل التجوية في ورقة البحث الحالية ـ تمت دراسة الصخور القلوية في منطقتين مختارتين في جنوب الصحراء الثرقية

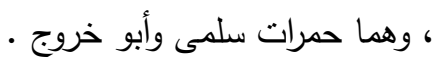

تم عمل دراسة حقلية وو صف معدني وتحاليل كيميائية لهذه الصخور واسفرت النتائج عن تصنيف صخور حمرات سلمي

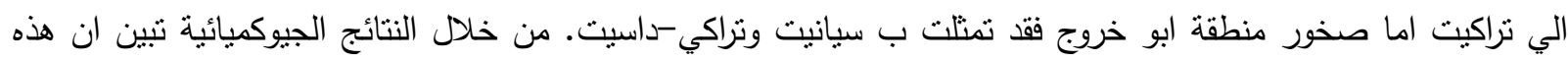
الصخور قلوية وتكونت في نظام أوروجيني ، نم عمل اختبارات المتانة وقوة الضغط الحر و مقاومة الصخور القلوية للعوامل الجوية الطبيعية .

و قد أظهرت نتائج قوة الانضغاط الحر والمتانة لمنطقة حمرات سلمى وسيانيت منطقة أبو خروج قوة قوية جدا. نم الحصول

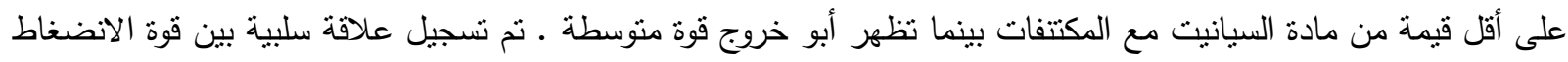
والمتانة بينما وجود المكتنفات والعروق والنسيج بورفيري يخلق علاقة ضعيفة. هناك علاقة خطية بين قوة الانضغاط وبعض

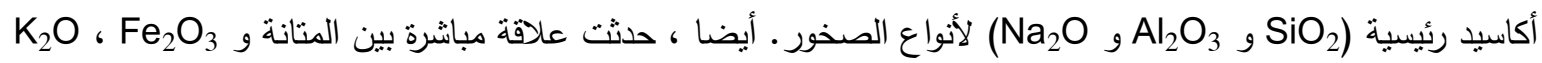

